\title{
LITHUANIAN OLYMPIC BASKETBALL PLAYERS' NUTRITION DURING THE TRAINING MEZZO-CYCLES DESIGNED FOR STRENGTH TRAINING
}

\author{
Marius Baranauskas ${ }^{1,3}$, Linas Tubelis ${ }^{2,3}$, Rimantas Stukas ${ }^{1}$, Edmundas Švedas ${ }^{4}$, \\ Laimutė Samsoniené $\dot{1}^{1}$, Diana Karanauskiené $\dot{~}^{5}$ \\ Vilnius Universityl, Vilnius, Lithuania, \\ Lithuanian University of Educational Sciences ${ }^{2}$, Vilnius, Lithuania \\ Lithuanian Olympic Sports Centre ${ }^{3}$, Vilnius, Lithuania \\ Lithuanian Sports Medicine Centre 4 , Vilnius, Lithuania \\ Lithuanian Sports University, Kaunas, Lithuania
}

\begin{abstract}
Research background and hypothesis. Unbalanced nutritional status, incorrect qualitative and quantitative content of nutritional and bioactive substances (nutrition value) for athletes in strength and speed sports can have a negative impact on acid-base homeostasis and physical working performance. Hypothesis - there is a dietary acidbase balance in the Lithuanian Olympic basketball team players' food rations.

Research aim was to assess dietary acid-base balance in Lithuanian high-performance basketball players during the training mezzo-cycles designed for strength training.

Research methods. In the general preparation period, Lithuanian Olympic Team basketball players $(\mathrm{n}=52)$, aged $18.0 \pm 1.9$ years, training $197.9 \pm 58.7 \mathrm{~min}$ a day, 6 days a week on average, were tested. Body composition analysis of athletes was performed using bioelectrical impedance analysis (BIA) method. Applying the survey method we investigated and assessed the nutritional status of basketball players, possible effect of their dietary intake on potential renal acid load (PRAL) and net endogenous acid production (NEAP).

Research results. The dietary PRAL of more than half (67.3\%) of subjects was positive $(8.5 \pm 49.0 \mathrm{mEq} / \mathrm{day})$. Basketball players' protein intake was positively related to dietary PRAL $(r=0.408, p=0.003)$. Protein intake of $20.5 \%$ of male basketball players on average was $2.6 \pm 0.7 \mathrm{~g} / \mathrm{kg}$ body weight, and their dietary PRAL was $75.5 \pm$ $22.8 \mathrm{mEq} /$ day, NEAP $-128.5 \pm 23.7 \mathrm{mEq} /$ day.

Discussion and conclusions. If high-protein diet (protein intake meets $1.8-2.0 \mathrm{~g} / \mathrm{kg} \mathrm{BW}$ ) is followed, basketball players' nutritional habits should be changed. Athletes are recommended to consume significantly more fresh fruits and vegetables and/or enrich the normal diet by sodium bicarbonate and/or beta-alanine dietary supplements.
\end{abstract}

Keywords: basketball, acid-base balance, renal acid overload.

\section{INTRODUCTION}

$\mathrm{T}$ The maintenance of homeostasis plays a key role in health and sports performance. As such, tissue and blood $\mathrm{pH}$ levels, once perturbed, must be returned to normal ranges. Basal metabolism generates organic acids while intensive exercise can cause transient increases of the acid load (Robergs et al., 2004). For the elimination of a proton surplus, the body has several buffering systems with a crucial role for the lungs and kidneys. One component that influences acid-base balance in the human body is the composition of the diet. Researchers found a strong relation between the composition of the diet and the urine $\mathrm{pH}$, and introduced the estimated "potential renal acid load" (PRAL) of food items (expressed 
in milli-equivalents (mEq) $\mathrm{H}+$ per $100 \mathrm{~g}$ ) (Remer, 2001). Fruits and vegetables have a negative PRAL which means that they potentially contribute in buffering hydrogen ions. Foods with high protein and phosphorus content such as meat and cheese have a positive PRAL, and hence potentially increase hydrogen ion production.

The estimated diet-dependent net endogenous acid production (NEAP) can be calculated as the sum of organic anions from the basal metabolism and the PRAL of all consumed food items (Frassetto et al., 2007). It has been suggested that the long-term net acid excretion should not exceed $100-120 \mathrm{mEq} /$ day since this may result in a maximal renal stimulation of acid, decreasing the plasma bicarbonate availability (Remer et al., 2003; Remer, Manz, 2003).

Basketball is a team sport where athletes perform high-intensity physical loads of moderate or long duration with recurrent low-intensity intervals of rest. Basketball players are strength-power athletes. Strength-power parameters are the main predictors of sprinting performance and resistance-based activity. Sprinting is a short burst of activity of high intensity relying primarily on alactic and lactic anaerobic energy systems and in case of repeated sprint exercise, aerobic metabolism also becomes involved (Berg et al., 2010). Especially during longer sprints or when rest periods between repetitions are too short to allow complete recovery, sprint athletes have to deal with high amounts of protons causing metabolic acidosis (Robergs et al., 2004).

Thus basketball players' unbalanced nutritional status, incorrect qualitative and quantitative content of nutritional and bioactive substances (nutrition value) can have a negative impact on acid-base homeostasis, anaerobic fitness parameters and slow down the adaptation to exercise training. In Lithuania there are no scientifically valid data on the impact of elite basketball players' nutrition on the body acid-base homeostasis. Optimization recommendations for players' nutrition have not been established though they would help improve the preparation of athletes for national and international championships. Research aim was to assess dietary acid-base balance in Lithuanian high-performance basketball players.

\section{RESEARCH METHODS}

Participants. In the general preparation period of 2011-2012, Lithuanian Olympic Team basketball players $(\mathrm{n}=52)$, included into the lists of athletes approved by the orders of the Department of Physical Education and Sport, were included in the research. The mean age of the research participants was $18.0 \pm 1.9$ years; their training status was $6.8 \pm 2.5$ years. Athletes trained 6 days a week on average. The duration of one training session was $117.1 \pm 15.3 \mathrm{~min}$, and the duration of one-day training was $197.9 \pm 58.7 \mathrm{~min}$. The research sample consisted of $75 \%$ of men and $25 \%$ of women. In addition, athletes were engaged in weight-training aiming at muscular hypertrophy and strength.

Anthropometric measures. The height of basketball players was measured using the electronic scales at the Lithuanian Sports Medicine Centre. Body composition analysis of athletes was performed at the Lithuanian Olympic Sports Centre using Body Composition Analyser X-SCAN using bioelectrical impedance analysis (BIA) method (American College of Sports Medicine, 2009) applied in research with athletes. We also established athletes' body weight (BW, kg), fatfree mass (FFM, $\mathrm{kg}$ and \%) and body fat (BF, $\mathrm{kg}$ and \%), as well as body mass index) (BMI) (The World Health Report, 2002) and muscle and fat mass index (MFMI) (Skernevičius et al., 2004).

Physical activity level. To estimate total energy expenditure, basal metabolic rate we used Harris-Benedict equation (Harris, Benedict, 1919). To estimate exercise energy expenditure, we used metabolic equivalent records over a 24 -hour period (Ainsworth et al., 2011). 24-hour records of physical activity were collected on the same day participants recorded their dietary intakes to estimate physical activity level during a period of active training.

Dietary intake. Nutritional status of athletes in the Lithuanian Olympic Team was assessed after 24-hour food recall. We recorded the data for each athlete's consumed food and dishes. Dietary recall was investigated using special Atlas of Foodstuffs and Dishes sizes. In accordance with tables of food composition, we calculated the chemical composition of athletes' diet) (Sučilienè, Abaravičius, 2002). We estimated athletes' carbohydrate, protein, dietary fat, phosphorus, calcium, potassium and magnesium intakes. Macronutrient intake was assessed according to the recommendations provided in research literature (American College of Sports Medicine, 2009; Burke, 2010; Kreider et al., 2010). Compliance of mineral intake with RDI was assessed referring to recommended daily intake norms approved in Lithuania (Rekomenduojamos paros maistiniu medžiagu ir energijos normos, 1999). 
PRAL and the diets. The following formula was used to estimate the net endogenous acid production (NEAP) (Remer, Manz, 1995):

Estimated NEAP (mEq/day) $={ }^{1}$ PRAL $\left(\mathrm{mEq} /\right.$ day) $+{ }^{2} \mathrm{OA}(\mathrm{mEq} /$ day) ; whereby PRAL denotes estimated dietary potential renal acid load and OA denotes estimated urinary organic anions, with the 2 components it is calculated as follows:

PRAL $(\mathrm{mEq} /$ day $)=(0.49 \times$ protein $(\mathrm{g} /$ day $))+$ $(0.037 \times$ phosphorus $(\mathrm{mg} /$ day $))-(0.021 \times$ potassium $(\mathrm{mg} /$ day $))-(0.026 \times$ magnesium $(\mathrm{mg} /$ day $))-(0.013 \times$ calcium (mg/day)) (2)

OA $(\mathrm{mEq} /$ day $)=$ individual body surface area $^{3} \times 41 / 1.73$.

Body surface area was calculated according to the formula proposed by D. Du Bois and E. F. Du Bois (Du Bois, D., Du Bois, E. F., 1916):

Individual Body surface area $\left(\mathrm{m}^{2}\right)=0.007184 \times$ (height $(\mathrm{cm})^{0.725} \times$ weight $\left.(\mathrm{kg})^{0.425}\right)$.

Data analysis. Statistical data analysis was carried out using the SPSS (Statistical Package for Social Sciences) v. 15.0. Data analysis was carried out using conventional methods of descriptive statistics: calculation of arithmetic means, standard deviations (SD). Student's t-test was used for the comparison of means between two independent groups of respondents. Hypothesis was verified using the level of significance of $\alpha=0.05$. The significance level was set at $\mathrm{p}<0.05$. Some calculations were made using Pearson's correlation coefficient (r).

\section{RESEARCH RESULTS}

Body composition analysis of athletes in the Lithuanian Olympic team (height, BW, FFM, FM, MM, BMI and MFMI) is given in Table 1. Regardless of gender, basketball players' BMI ranges within the normal range, but the male basketball players' BW ( $\mathrm{kg}$ and $\%, \mathrm{p}<0.0001)$, FFM ( $\mathrm{kg}$ and $\%, \mathrm{p}<0.0001), \mathrm{MM}(\mathrm{kg}$ and $\% ; \mathrm{p}<0.0001)$ are higher than those of female basketball players. In addition, the male basketball players' MFMI $(4.5 \pm 1.3)$ (estimated as the average) at a higher level conforms to the requirements for elite athletes compared to the female basketball players' MFMI which is too low $(2.9 \pm 0.4)$ (seen as too small). This is attributed to the purposefully increased $\mathrm{MM}$ in men basketball players.

Table 1. Sports experience and anthropometric data of Lithuanian Olympic team basketball players $(\mathbf{n}=\mathbf{5 2})$

\begin{tabular}{|c|c|c|c|c|c|}
\hline \multirow{2}{*}{$\begin{array}{l}\text { Sports experience, height and body } \\
\text { mass components }\end{array}$} & Total & Male $^{1}$ & Female $^{2}$ & \multicolumn{2}{|c|}{ t-test $t^{1 / 2}$} \\
\hline & \multicolumn{3}{|c|}{ Mean \pm SD } & $t$ & $\mathbf{p}$ \\
\hline Sports experience, yr & $9.01 \pm 3.3$ & $9.2 \pm 3.3$ & $6.8 \pm 2.5$ & 1.234 & 0.225 \\
\hline Workouts per week, no. & $6.0 \pm 0.8$ & $6.0 \pm 0.8$ & $5.7 \pm 0.6$ & 0.779 & 0.44 \\
\hline Workouts per day, no. & $1.6 \pm 0.5$ & $1.6 \pm 0.5$ & $2.0 \pm 3$ & -4.873 & $<0.0001$ \\
\hline Average training time per day, min & $117.1 \pm 15.3$ & $118.5 \pm 14.6$ & $100.0 \pm 17.3$ & 2.094 & 0.043 \\
\hline Total training time per day, min & $197.9 \pm 58.7$ & $205.4 \pm 65.7$ & $175.4 \pm 16.6$ & 2.613 & 0.012 \\
\hline Age, yr & $18.0 \pm 1.9$ & $18.6 \pm 1.8$ & $16.1 \pm 0.5$ & 8.115 & $<0.0001$ \\
\hline Height, cm & $192.7 \pm 11.6$ & $197.6 \pm 8.0$ & $177.8 \pm 7.0$ & 7.93 & $<0.0001$ \\
\hline $\mathrm{BW}, \mathrm{kg}$ & $81.7 \pm 11.7$ & $85.7 \pm 9.9$ & $69.5 \pm 8.0$ & 5.357 & $<0.0001$ \\
\hline FFM, kg & $65.8 \pm 9.7$ & $70.3 \pm 5.8$ & $52.1 \pm 4.7$ & 10.245 & $<0.0001$ \\
\hline FFM, \% & $80.5 \pm 4.4$ & $82.3 \pm 3.3$ & $75.2 \pm 2.8$ & 6.855 & $<0.0001$ \\
\hline $\mathrm{MM}, \mathrm{kg}$ & $61.0 \pm 9.0$ & $65.3 \pm 5.2$ & $48.1 \pm 4.3$ & 10.687 & $<0.0001$ \\
\hline MM, \% & $74.7 \pm 4.4$ & $76.5 \pm 3.3$ & $69.4 \pm 2.7$ & 6.932 & $<0.0001$ \\
\hline $\mathrm{FM}, \mathrm{kg}$ & $16.0 \pm 4.3$ & $15.5 \pm 4.5$ & $17.4 \pm 3.7$ & 1.376 & 0.175 \\
\hline FM, \% & $19.5 \pm 4.4$ & $17.7 \pm 3.3$ & $24.8 \pm 2.8$ & -6.847 & $<0.0001$ \\
\hline $\mathrm{PM}, \mathrm{kg}$ & $13.8 \pm 2.2$ & $14.8 \pm 1.3$ & $10.6 \pm 0.9$ & 10.793 & $<0.0001$ \\
\hline PM, \% & $16.8 \pm 1.2$ & $17.3 \pm 0.9$ & $15.3 \pm 0.7$ & 7.451 & $<0.0001$ \\
\hline $\mathrm{M}, \mathrm{kg}$ & $4.7 \pm 0.7$ & $5.0 \pm 0.6$ & $4.0 \pm 0.4$ & 5.787 & $<0.0001$ \\
\hline M, \% & $5.8 \pm 0.1$ & $5.8 \pm 0.1$ & $5.8 \pm 0.1$ & 1.306 & 0.198 \\
\hline $\mathrm{BMI}, \mathrm{kg} / \mathrm{m}^{2}$ & $21.9 \pm 1.9$ & $22.0 \pm 1.9$ & $21.8 \pm 1.6$ & 0.233 & 0.825 \\
\hline MFMI & $4.1 \pm 1.3$ & $4.5 \pm 1.3$ & $2.9 \pm 0.4$ & 7.103 & $<0.0001$ \\
\hline
\end{tabular}

Note. Values are expressed as mean \pm SD; BW - Body Weight; FFM - Fat-free Mass; MM - Muscle Mass; FM - fat Mass; PM - Protein Mass; M - Body Minerals; BMI - Body Mass Index; MFMI - Muscle and Fat mass Index. Significant differences set by independent samples Student's t-test among groups: ${ }^{1}-$ Group $1,{ }^{2}-$ Group 2. 
Table 2. Dietary intake of Lithuanian Olympic team basketball players $(n=52)$

\begin{tabular}{|c|c|c|c|c|c|c|}
\hline \multirow{2}{*}{ Nutrition profile } & Male $(n=39)^{1}$ & Female $(\mathrm{n}=13)^{2}$ & \multicolumn{2}{|c|}{ Recommended for: } & \multicolumn{2}{|c|}{ t-test ${ }^{1 / 2}$} \\
\hline & \multicolumn{2}{|c|}{ Mean \pm SD } & Male & Female & $\mathbf{t}$ & $\mathbf{p}$ \\
\hline EI, kcal & $4521.2 \pm 1341.7$ & $2854.5 \pm 428.1$ & $\mathrm{EER}=5073.3 \pm 855.9$ & $\begin{array}{c}\mathrm{EER}=3685.85 \pm \\
308.6\end{array}$ & 6.790 & $<0,0001$ \\
\hline EI, kcal/kg BW & $52.9 \pm 14.8$ & $41.6 \pm 8.4$ & $\mathrm{EER}=59.2 \pm 7.2$ & $\mathrm{EER}=53.3 \pm 2.9$ & 3.365 & 0,002 \\
\hline $\mathrm{CHO}, \mathrm{g} / \mathrm{kg} \mathrm{BW}$ & $6.0 \pm 1.9$ & $5.4 \pm 1.3$ & \multicolumn{2}{|c|}{$7-10$} & 0.925 & 0.359 \\
\hline $\mathrm{CHO}, \%$ & $44.8 \pm 5.4$ & $52.0 \pm 5.1$ & \multicolumn{2}{|c|}{$>55$} & -4.239 & $<0.0001$ \\
\hline $\mathrm{PRO}, \mathrm{g} / \mathrm{kg} \mathrm{BW}$ & $1.9 \pm 0.6$ & $1.5 \pm 0.3$ & \multicolumn{2}{|c|}{$1.4-2.0$} & 2.270 & 0.028 \\
\hline FAT, $\%$ & $40.7 \pm 5.2$ & $33.5 \pm 4.2$ & \multicolumn{2}{|c|}{$20-30$} & 4.581 & $<0.0001$ \\
\hline $\mathrm{K}, \mathrm{mg}$ & $6926.8 \pm 2755.1$ & $4012.8 \pm 742.5$ & \multicolumn{2}{|c|}{2500} & 5.980 & $<0.0001$ \\
\hline $\mathrm{Ca}, \mathrm{mg}$ & $1434.5 \pm 612.8$ & $1447.8 \pm 484$ & \multicolumn{2}{|c|}{1000} & -0.071 & 0.944 \\
\hline $\mathrm{Mg}, \mathrm{mg}$ & $698.9 \pm 324.7$ & $472.6 \pm 82.2$ & \multicolumn{2}{|c|}{300} & 3.987 & $<0.0001$ \\
\hline $\mathrm{P}, \mathrm{mg}$ & $2524.8 \pm 784.7$ & $1830.1 \pm 403.5$ & \multicolumn{2}{|c|}{900} & 3.046 & 0.004 \\
\hline $\mathrm{Ca} / \mathrm{P}$ ratio & $0.6 \pm 0.2$ & $0.8 \pm 0.1$ & \multicolumn{2}{|c|}{0.75} & -4.177 & $<0.0001$ \\
\hline PRAL, $\mathrm{mEq}$ & $8.5 \pm 49.0$ & $15.0 \pm 17.8$ & \multicolumn{2}{|c|}{0} & -0.711 & 0.481 \\
\hline NEAP, mEq & $60.5 \pm 49.6$ & $59.2 \pm 19.3$ & \multicolumn{2}{|c|}{$<100$} & 0.140 & 0.889 \\
\hline
\end{tabular}

Note. Values are expressed as mean \pm SD; EI - Energy Intake; EER - Estimated Energy Requirement; BW - Body Weight; PRO - Protein; CHO - Carbohydrate; FAT - Fat; Ca - Calcium; P - Phosphorus; Mg - Magnesium; K - Potassium; RDI - Recommended Daily Intake; PRAL - Potential Renal Acid Load; NEAP - Net Endogenous Acid Production. Significant differences set by independent samples Student's t-test among groups: ${ }^{1}-$ Group $1,{ }^{2}-$ Group 2.

Dietary intake. The analysis of the nutritional status of basketball players showed that 24-hour energy intake (EI) of both male and female basketball players (respectively, $52.9 \pm 14.8 \mathrm{kcal} / \mathrm{kg}$ BW and $41.6 \pm 14.8 \mathrm{kcal} / \mathrm{kg} \mathrm{BW}$ ) was lower than the estimated energy requirements (EER)) (Table 2).

The evaluation of macronutrient intake for the players showed that regardless of gender, players' carbohydrate intake was less than recommended. Men basketball players' average dietary intake of carbohydrates $(6.0 \pm 1.9 \mathrm{~g} / \mathrm{kg} \mathrm{BW})$ did not differ from women players' carbohydrate intake $(5.4 \pm$ $1.9 \mathrm{~g} / \mathrm{kg} \mathrm{BW})(\mathrm{p}<0.0001)$ and it did not match the recommended intake $(7.0-10 \mathrm{~g} / \mathrm{kg} \mathrm{BW})$. Average protein intake in male and female basketball players' food rations, respectively $1.9 \pm 0.6 \mathrm{~g} / \mathrm{kg}$ BW and $1.5 \pm 0.3 \mathrm{~g} / \mathrm{kg} \mathrm{BW}$, met the recommended norms $(1.4-2.0 \mathrm{~g} / \mathrm{kg} \mathrm{BW})$, but men basketball players' protein intake was higher than that of women $(\mathrm{p}=0.028)$.

In the research we found that basketball players consumed more fat than it was recommended. This is confirmed by the energy supply rate $(40.7 \pm$ $5.2 \%$ of daily calories come from fat) in basketball players' diets, which exceeded the recommended norms. Meanwhile, the share of fat supply for energy intake in women basketball players' rations $(33.5 \pm 4.2 \%$ of daily calories come from fat) was significantly lower than that in men basketball players' rations $(\mathrm{p}<0.0001)$, and slightly higher than the recommended (20-30\%).

The analysis of the mineral status of athletes' diets (Table 2) showed that basketball players' phosphorus intake was higher than recommended, as well as the intake of base-forming dietary minerals such as potassium, magnesium, calcium. Contrary to women's diets, calcium and phosphorus intake in men basketball players' diets was unbalanced $(\mathrm{p}<0.0001)$. This was confirmed by the calcium and phosphorus ratio $(\mathrm{Ca} / \mathrm{P}$, $0.6 \pm 0.2)$ men basketball players' food rations that did not reach the recommended intake of 0.75 , which was determined by excess dietary intake of phosphorus. However, the optimal Ca/P $(0.8 \pm 0.1)$ was characteristic of women basketball players' diets.

Acid-base balance and diets. The assessment of Lithuanian Olympic team dietary PRAL showed that the dietary PRAL of more than half (67.3\%) basketball players was positive. Dietary PRAL of male basketball players $(8.5 \pm 49.0 \mathrm{mEq} / \mathrm{day}) \mathrm{did}$ not differ from the one of female basketball players $(15.0 \pm 17.8 \mathrm{mEq} /$ day $)$ and was positive $(\mathrm{p}=0.841)$ (Table 2).

Analysing the links between PRAL and nutrition value of basketball players' diets we found that greater protein intake was linked to positive dietary PRAL $(r=0.408, p=0.003)$ (Figure). 
Aiming at establishing if the chemical composition of athletes' dietary intake was proper for the maintenance of acid-base homeostasis, we evaluated the effect of nutrition on the body NEAP. For athletes it is important that long-term net acid excretion should not exceed $100 \mathrm{mEq} /$ day since this may result in a maximal renal stimulation of acid, decreasing the plasma bicarbonate availability)
(Remer et al., 2003; Remer, Manz, 2003). Though our male basketball players' average NEAP $(60.5 \pm 49.6 \mathrm{mEq} / \mathrm{day})$ did not differ from that of female basketball players $(59.2 \pm 19.3 \mathrm{mEq} /$ day $)$ $(\mathrm{p}=0.889)$ (Table 2$)$, NEAP of as many as $20.5 \%$ of Lithuanian Olympic team men basketball players was higher than $100 \mathrm{mEq} / \mathrm{day}$ and on average it was $128.5 \pm 23.7 \mathrm{mEq} /$ day (Table 3 ).

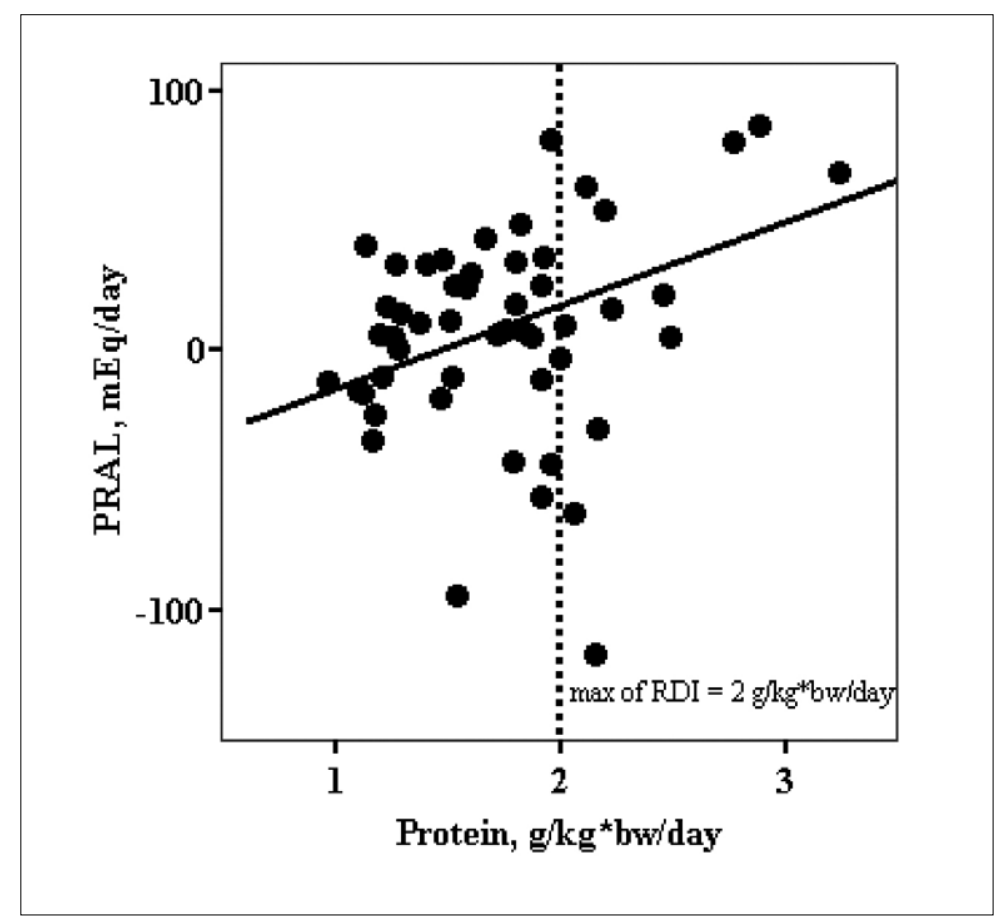

Figure. Relationship between PRAL (mEq/day) and dietary protein intake (g/kg body weight/day)

Note. RDI - Recommended Daily Intake; PRAL Potential Renal Acid Load. Pearson's correlation coefficient $\mathrm{r}-0.408, \mathrm{p}-0.003$.

Table 3. Daily intakes of protein and selected micronutrients and estimated potential renal acid load (PRAL) in Lithuanian Olympic team basketball players (by the net endogenous acid production (NEAP) groups)

\begin{tabular}{|c|c|c|c|c|c|c|}
\hline \multirow{2}{*}{ Nutrition profile } & \multicolumn{2}{|c|}{ NEAP< 100, $\mathbf{m E q} \mathbf{q}^{\mathbf{1}}$} & \multicolumn{2}{c|}{ NEAP $>\mathbf{1 0 0 ,} \mathbf{~ m E q}^{2}$} & \multicolumn{2}{c|}{ t-test $^{1 / 2}$} \\
\cline { 2 - 7 } & Minimum-Maximum & Mean \pm SD & Minimum-Maximum & Mean \pm SD & t & p \\
\hline PRO, g/kg BW & $1.0-2.5$ & $1.6 \pm 0.4$ & $1.8-3.7$ & $2.6 \pm 0.7$ & -5.631 & $<0.0001$ \\
\hline PRO, \% RDI & $48.9-124.8$ & $82.1 \pm 34.6$ & $91.5-183.3$ & $129.4 \pm 33.0$ & -3.935 & 0.004 \\
\hline P, mg & $1188.8-5247.9$ & $2232.0 \pm 761.5$ & $2502.1-3543.9$ & $3006.4 \pm 389.9$ & -2.794 & 0.007 \\
\hline P, \% RDI & $99.1-583.1$ & $210.2 \pm 19.2$ & $208.5-393.8$ & $294.0 \pm 67.9$ & -2.496 & 0.016 \\
\hline K, mg & $2570.8-17411.7$ & $6235.3 \pm 2928.0$ & $4521.8-7902.3$ & $5994.8 \pm 1122.2$ & 0.228 & 0.821 \\
\hline K, \% RDI & $102.8-696.5$ & $249.4 \pm 117.1$ & $180.9-316.1$ & $239.8 \pm 44.9$ & 0.228 & 0.821 \\
\hline Ca, mg & $680.6-3964.5$ & $1425.8 \pm 576.7$ & $1012.2-2903.6$ & $1504.0 \pm 625.7$ & -0.349 & 0.729 \\
\hline Ca, \% RDI & $69.4-396.5$ & $165.5 \pm 108$ & $113.7-290.4$ & $167.2 \pm 63.2$ & -0.07 & 0.945 \\
\hline Mg, mg & $310.8-2111.8$ & $638.8 \pm 323.6$ & $514.0-792.7$ & $661.5 \pm 107.4$ & -0.195 & 0.846 \\
\hline Mg, \% RDI & $77.7-703.9$ & $194.0 \pm 90.2$ & $128.5-264.2$ & $194.2 \pm 49.3$ & 0.364 & 0.995 \\
\hline PRAL (mEq) & $-116.9-42.8$ & $-1.8 \pm 34.6$ & $48.7-121.1$ & $75.5 \pm 22.8$ & -6.054 & $<0.0001$ \\
\hline NEAP (mEq) & $-59.3-97.1$ & $47.8 \pm 34.1$ & $104.2-173.5$ & $128.5 \pm 23.7$ & -5.68 & $<0.0001$ \\
\hline
\end{tabular}

Note. Values are expressed as mean $\pm \mathrm{SD}$, minimum and maximum values; $\mathrm{BW}$ - Body Weight; $\mathrm{PRO}$ - Protein; $\mathrm{Ca}$ - Calcium; $\mathrm{P}$ - Phosphorus; Mg - Magnesium; K - Potassium; PRAL - Potential Renal Acid Load; RDI - Recommended Daily Intake; NEAP - Net Endogenous Acid Production. Significant differences set by independent samples Student's t-test among groups: ${ }^{1}-$ Group $1,{ }^{2}-$ Group 2 . 
As we see in Table 3, men basketball players' (NEAP $>100 \mathrm{mEq} /$ day) protein intake $(2.6 \pm 0.7 \mathrm{~g} / \mathrm{kg}$ body mass) exceeded the recommended intake 1.3 times, and phosphorus intake $(3006.4 \pm 289.9 \mathrm{mg})-3$ times. For athletes with NEAP $>100 \mathrm{mEq} /$ day, protein and phosphorus intakes were statistically significantly higher compared to protein and phosphorus intakes of those athletes whose NEAP $<100 \mathrm{mEq} / \mathrm{day}(\mathrm{p}<0.0001$ and $\mathrm{p}=0.007$ ). It should be noted that too high NEAP in the body can be found when the protein intake is $1.8 \mathrm{~g} / \mathrm{kg}$ body mass.

When the diet is high in protein, lower dietary PRAL and lower NEAP can be ensured by adequate intake levels of minerals, such as potassium, calcium and magnesium. Research findings showed that for athletes with NEAP $>100 \mathrm{mEq} /$ day, potassium intake $(5994.8 \pm 1122.2 \mathrm{mg})$, calcium intake $(1504.0 \pm 625.7 \mathrm{mg})$ and magnesium intake $(661.5 \pm$ 107.4) exceeded RDI 1.7-2.5 times. However, potassium, calcium and magnesium intakes of basketball players with NEAP $>100 \mathrm{mEq} / \mathrm{day}$ did not differ statistically significantly from those of players with NEAP $<100 \mathrm{mEq} /$ day $(\mathrm{p}=0.821$, $\mathrm{p}=0.729, \mathrm{p}=0.995)($ Table 3$)$.

\section{DISCUSSION}

Daily physical performance in the training zone of high intensity determines stress of buffering systems. Research has shown that even moderate physical exercise causes metabolic changes that affect acid-base homeostasis in skeletal muscles and other tissues (Lindinger, 1995). Meanwhile, due to the effect of high-intensity training, blood $\mathrm{pH}$ can drop from 7.4 to 7.1 per $1 \mathrm{~min}$, which is felt as very fast muscle fatigue, resulting in a decrease of anaerobic fitness (Robergs et al., 2004).

When training is extremely intense, highprotein and low-carbohydrate diet can result in metabolic acidosis and have negative influence on performance (Robergs et al., 2004). Much attention is paid to protein intake. A diet high in protein significantly reduces dietary PRAL and increases NEAP in the body. Long-term NEAP of 100-120 mEqv/day and more conditions maximal renal stimulation of acid, and the decrease of the plasma bicarbonate availability correlates with a long-term net acid excretion ion (100-120 mEq/day) (Remer et al., 2003; Remer, Manz,2003).Carbohydrateintakeofourinvestigated athletes did not reach the recommended minimum, and protein intake depended on basketball players' gender. The average protein intake of female basketball players was $1.5 \pm 0.3 \mathrm{~g} / \mathrm{kg}$ body mass. Significantly higher protein intake was typical of male basketball players who enhanced muscle hypertrophy. We established that protein intake of $20.5 \%$ of Lithuanian elite basketball players was higher than $1.8-2.0 \mathrm{~g} / \mathrm{kg}$ body mass, and their NEAP was found to be above the proposed cut off $100 \mathrm{mEq} / \mathrm{day}$, suggesting that the buffering systems of the body would be stressed to the proposed limit) (Remer, 2001; Remer et al., 2003; Remer, Manz, 2003). In this case metabolic acidosis could be normalized changing dietary habits (ensuring low dietary PRAL) (Pizzorno et al., 2010) or using specific dietary supplements (Derave, 2011). Research has established that higher consumption of fruit and vegetables increases potassium and magnesium intake leading to increased production of base in the body (Tucker et al., 1999). Aiming at increasing buffering capacity and improving highintensity anaerobic capacity, Lithuanian Olympic team basketball players are recommended the intake of buffering agents, such as sodium bicarbonate: $0.18-0.30 \mathrm{~g} / \mathrm{kg}$ BW of sodium bicarbonate intake help to maintain higher blood $\mathrm{pH}$ and thus improve aerobic capacity indices during high-intensity training (McNaughton et al., 1999; Requena et al., 2005). While training bicarbonate supplementation possibly delays intracellular acidification or the body is supplied with the additional amount of bicarbonate, thereby increasing the buffering capacity (Lindh et al., 2008; Derave, 2011). Besides, aiming at improving performance when training is extremely intense, Lithuanian basketball players are recommended 4-10 week dietary beta-alanine supplementation, respectively 1.5-6.0 g a day (Baguet et al., 2010; Derave, 2011). Increasing carnosine levels in skeletal muscles, beta-alanine acts as an intracellular buffer. Carnosine helps muscle cells to remove protons, which are further affected by the circulating buffers (such as bicarbinate) in the extracellular fluids and thus acidosis is staved off and rapid muscle fatigue is avoided (Baguet et al., 2010; Sweeney et al., 2010).

Summing up, high-protein diet, e. g. high intakes of meat, cheese, eggs and other food products, in Lithuanian elite male basketball players is recommended to be changed by high-protein diets full of fruit and vegetables to reduce dietary PRAL and NEAP in the body. Basketball players, overcoming strenuous exercise, are recommended supplementing the regular diets by sodium 
bicarbonate and beta-alanine dietary supplements in relevant doses. Supplementation of food rations with buffering agents (e. g. bicarbonates) causes ergogenic effect, improves performance, but it cannot replace conventional foods reducing PRAL. For this reason, further research is needed to assess the impact of the higher intake of fresh fruit and vegetables on physical performance parameters for basketball players in the course of their training.

\section{CONCLUSIONS AND PERSPECTIVES}

1. Nutrition of Lithuanian Olympic basketball teams does not meet the requirements: basketball players' diet is too high in dietary fat and is too low in carbohydrates. One in five $(20.5 \%)$ male basketball players uses high-protein diet (protein intake exceeds $1.8-2.0 \mathrm{~g} / \mathrm{kg} \mathrm{BW}$ ), which conditions dietary acid-base misbalance and excessive net endogenous acid production in the body.

2. If high-protein diet (protein intake meets $1.8-2.0 \mathrm{~g} / \mathrm{kg} \mathrm{BW}$ ) is taken, basketball players' nutritional habits should be changed. Aiming at ensuring dietary acid-base balance and maximal muscular adaptations in response to anaerobic training, basketball players should use higher levels (two or more times exceeding RDI) of minerals, potassium, calcium and magnesium. Athletes are recommended to consume significantly more fresh fruits and vegetables and/or enrich the normal diet by sodium bicarbonate and beta-alanine dietary supplements.

\section{REFERENCES}

Ainsworth, B. E., Haskell, W. L., Herrmann, S. D. et al. (2011). Compendium of physical activities: A second update of codes and MET values. Medicine \& Science in Sports \& Exercise, 43 (1), 1575-1581.

American College of Sports Medicine, American dietetic Association, and Dieticians of Canada. Nutrition and Athletic Performance. Joint Position Statement. (2009). Medicine \& Science in Sports \& Exercise, 41, 709-731.

Baguet, A., Koppo, K., Pottier, A., Derave, W. (2010). Beta-alanine supplementation reduces acidosis but not oxygen uptake response during high-intensity cycling exercise. European Journal of Applied Physiology, 108, 495-503.

Berg, K., Buresh, R., Parks, L. et al. (2010). Oxygen cost of sprint training. Journal of Sports Medicine and Physical Fitness, 50, 25-31.

Burke, L. M. (2010). Fuelling strategies to optimize performance: Training high or training low? Scandinavian Journal Medicine \& Science in Sports, 20 (2), 48-58.

Derave, W. (2011). Nutritional supplements for team sports: Focus on pH buffers. Sport nutrition conference (pp. 17-20). Colorado Springs.

Du Bois, D., Du Bois, E. F. (1916). A formula to estimate the approximate surface area if height and weight be known. Archives of Internal Medicine, 17, 863-871.

Frassetto, L. A., Lanham-New, S. A., MacDonald, H. M. et al. (2007). Standardizing terminology for estimating the diet-dependent net acid load to the metabolic system. Journal of Nutrition, 137, 1491-1492.

Harris, J., Benedict, F. (1919). A Biometric Study of Basal Metabolism in Man. Philadelphia, PA: Lippincott.

Kreider, R. B., Wilborn, C. D., Taylor, L. et al. (2010). ISSN exercise and sport nutrition review: Research and recommendations. Journal of the International Society of Sports Nutrition, 7, 7. Internet link: http://www.jissn. com/content $/ 7 / 1 / 7$.

Lindh, A. M., Peyrebrune, M. C., Ingham, S. A. et al. (2008). Sodium bicarbonate improves swimming performance. International Journal of Sports Medicine, 29, 519-523.

Lindinger, M. I. (1995). Origins of $\left[\mathrm{H}^{+}\right]$changes in exercising skeletal muscle. Canadian Journal of Applied Physiology, 20 (3), 357-368.

McNaughton, L., Backx, K., Palmer, G. et al. (1999). Effects of chronic bicarbonate ingestion on the performance of high intensity work. European Journal of Applied Physiology, 80, 333-336.

Pizzorno, J., Frassetto, L. A., Katzinger, J. (2010). Diet-induced acidosis: Is it real and clinically relevant? British Journal of Nutrition, 103 (8), 1185-1194.

Rekomenduojamos paros maistinių medžiagų ir energijos normos. (1999). Valstybès žinios, 102, 2936.

Remer, T., Dimitriou, T., Manz, F. (2003). Dietary potential renal acid load and renal net acid excretion in healthy, free-living children and adolescents. American Journal of Clinical Nutrition, 77, 1255-1260.

Remer, T. (2001). Influence of nutrition on acidbase balance-metabolic aspects. European Journal of Nutrition, 40, 214-220.

Remer, T., Manz, F. (2003). High meat diet, acid-base status and calcium retention. Journal of Nutrition, 133, 32-39.

Requena, B., Zabala, M., Padial, P., Feriche, B. (2005). Sodium bicarbonate and sodium citrate: Ergogenic aids? Journal of Strength \& Conditioning Research, 19, 213-224.

Robergs, R. A., Ghiasvand, F., Parker, D. (2004). Biochemistry of exercise-induced metabolic acidosis. 
American Journal of Physiology - Regulatory, Integrative and Comparative Physiology, 287, 502-516.

Skernevičius, J., Raslanas, A., Dadelienė, R. (2004). Sporto mokslo tyrimų metodologija. Fizinio išsivystymo tyrimai. Antropometrija (pp. 51-58). Vilnius.

Sučiliene, S., Abaravičius, A. (2002). Maisto produktu sudetis. Vilnius. P. 10-315.

Sweeney, K. M., Wright, G.A., Glenn, B.A., Doberstein, S. T. (2010). The effect of beta-alanine supplementation on power performance during repeated sprint activity. Journal of Strength \& Conditioning Research, 24, 79-87.

The World Health Report 2002. (2002). Reducing Risks, Promoting Healthy Life. Geneva: WHO.

Tucker, K. L., Hannan, M. T, Chen, H. et al. (1999). Potassium, magnesium, and fruit and vegetable intakes are associated with greater bone mineral density in elderly men and women. American Journal of Clinical Nutrition, 69, 727-736.

\title{
LIETUVOS OLIMPINĖS PAMAINOS KREPŠININKŲ MITYBA TRENIRUOTE்S MEZOCIKLU TAIKANT PADIDINTUS KRŪVIUS JËGAI UGDYTI
}

\author{
Marius Baranauskass ${ }^{1,3}$, Linas Tubelis ${ }^{2,3}$, Rimantas Stukas ${ }^{1}$, Edmundas Švedas $^{4}$, \\ Laimutė Samsoniené ${ }^{1}$, Diana Karanauskiené $\dot{~}^{5}$ \\ Vilniaus universitetas ${ }^{l}$, Vilnius, Lietuva \\ Vilniaus edukologijos universitetas ${ }^{2}$,Vilnius, Lietuva \\ Lietuvos olimpinis sporto centras ${ }^{3}$, Vilnius, Lietuva \\ Lietuvos sporto medicinos centras ${ }^{4}$, Vilnius, Lietuva \\ Lietuvos sporto universitetas ${ }^{5}$, Kaunas, Lietuva
}

\section{SANTRAUKA}

Tyrimo pagrindimas ir hipotezė. Jègą ir greitumą ugdančiu sportininkų netinkama maisto raciono maistinių ir biologiškai aktyvių medžiagų sudètis gali neigiamai paveikti rūgščiu ir šarmų pusiausvyros homeostazę ir fizinio darbingumo rodiklius. Hipoteze - rūgštinès ir šarminès medžiagos Lietuvos olimpinės pamainos krepšininkų maisto racione tinkamai subalansuotos.

Tikslas - ivvertinti Lietuvos olimpinės pamainos krepšininkų maisto raciono rūgštiniu ir šarminių medžiagu sudètị ir jų galimą poveikị sportininkų inkstų apkrovai rūgštimis.

Metodai. Parengiamuoju varžybų laikotarpiu ištirti kasdien po $197.9 \pm 58.7$ min šešias dienas per savaitę besitreniruojantys $18.0 \pm 1.9$ metų amžiaus 52 Lietuvos didelio meistriškumo krepšininkai. Panaudojus BIA tetra poliarini elektrodų metodą ivvertinta krepšininkų kūno sandara. Pritaikius apklausos metodą ištirta krepšininkų faktinè mityba, ivertintas maisto raciono galimas poveikis inkstų apkrovai rūgštimis (PRAL) ir nustatyta bendra organinių rūgščiu gamyba organizme (NEAP).

Rezultatai. 67.3\% krepšininkų maisto raciono PRAL ( $8.5 \pm 49.0$ mekv./diena) yra teigiamas. Krepšininkų suvartojamas baltymų kiekis teigiamai koreliuoja su maisto raciono PRAL $(r=0.408, p=0.003) .20 .5 \%$ krepšininku vyru vidutiniškai suvartoja $2.6 \pm 0.7 \mathrm{~g} / \mathrm{kg}$ kūno masès baltymu, jų maisto raciono PRAL sudaro $75.5 \pm 22.8 \mathrm{mekv}$./dieną, $\mathrm{NEAP}-128.5 \pm 23.7 \mathrm{mekv}$./diena.

Aptarimas ir išvados. Taikant padidinto baltymų kiekio (1.8-2.0 g/kg kūno masès) mitybą krepšininkų mitybos ipročiai turi būti keičiami. Krepšininkams rekomenduojama suvartoti daug didesnị šviežiu vaisių ir daržovių kiekị ir/arba iprastinę mitybą papildyti natrio bikarbonato ir/arba betaalanino maisto papildais.

Raktažodžiai: krepšinis, rūgščių ir šarmų pusiausvyra, galima inkstų apkrova rūgštimis.

Gauta 2013 m. liepos 27 d.

Received on July 27, 2013

Priimta 2013 m. rugsejo $9 \mathrm{~d}$.

Accepted on 9 September, 2013
Corresponding author Marius Baranauskas Lithuanian Olympic Sports Centre

Ozo str. 39, Vilnius LT-07171

Lithuania

Tel +37068384462

E-mail marius.baranauskas9@gmail.com 